\title{
A REDE DE CIDADES DO VALE DO JEQUITINHONHA NOS SÉCULOS XVIII E XIX
}

\author{
André Velloso(*) \& Ralfo Matos(**)
}

\begin{abstract}
The Jequitinhonha Valley, located in northeast Minas Gerais, presents itself in critical socio-economic state. Its undervelopment and its peripheral condition in relation to the other areas of the state have become chronic. Some of the contexts that have originated the current situation can be traced back to previous socio-spacial configurations. The geo-historical analysis of these contexts surely allows a better understanding of the issue. The study of processes related to the structuring of an urban network in the region, iniciated by the $18^{\text {th }}$ century, helps to elucidate aspects related to the current state of affairs of the Valley. In this study the networks, constituted by road linkages, flows and urban localities associated with the structure of the territory, are analysed, taking into consideration that the improvement of the local conditions is deeply linked to a broader understanding of its local history.
\end{abstract}

\section{INTRODUÇÃO}

O conceito original de "rede de cidades" foi útil para designar conexões espaciais focalizando o sistema de comunicações. Com o tempo, o seu uso veio focalizar a existência de conjuntos estruturados de cidades, nos quais houvessem relações econômicas constantes e significativas.

Em Geografia foram importantes os estudos sobre redes urbanas, notadamente a partir das contribuições de Christaller, Losh e Brian Berry. Privilegiou-se então a utilização dos métodos lógico-matemáticos, através dos quais procurava-se identificar características dominantes passíveis de mensuração, enfatizando aspectos funcionais, níveis de hierarquia e graus de influência entre as localidades.

No Brasil, tais estudos são escassos. Não causa surpresa o relativo desconhecimento da evolução da rede urbana brasileira, principalmente daquela constituída por cidades médias e pequenas, do ponto de vista do tamanho populacional. ${ }^{1}$

É interessante lembrar que, em Minas Gerais, algumas pesquisas empreendidas na década de setenta se orientavam pela busca do conhecimento acerca das cidades médias. Acreditava-se que através do incremento de alguns destes núcleos urbanos, poderiam ser minimizados problemas relacionados ao crescimento das grandes cidades mineiras ${ }^{2}$.

A rede de cidades de Minas Gerais, um dos primeiros Estados a ser urbanizado no país, remonta ao século XVIII, com a descoberta do ouro e do diamante. ${ }^{3}$ Com a perda do dinamismo econômico estritamente ligado à atividade minerária ocorreu um movimento populacional centrífugo, materializando a ocupação das áreas periféricas à região central, o que fez expandir a fronteira da província tanto para o sul-sudoeste quanto para o norte-nordeste.

Tendo em vista o processo de formação e as "novas" inserções do Estado na economia nacional surge como corolário a existência de uma série de pequenas e médias cidades, muitas das quais esquecidas pela historiografia convencional. A difícil incorporação destas localidades pelos sistemas mais dinâmicos da economia nacional colocou-as, de certo modo, à margem do processo de desenvolvimento, não obstante o fato de várias delas já terem desempenhado um importante papel histórico na estruturação sócio-espacial do território mineiro. Entre estas é possível destacar aquelas que têm sua origem ligadas aos primórdios de Minas Gerais: os "lugares urbanos"4 surgidos com o ciclo do ouro, alguns deles localizados no Vale do Jequitinhonha, no nordeste mineiro.

Para pesquisar estes lugares, foram adotados cortes analíticos temporais e espaciais. Espacialmente foram

1 - Após 1930, surgiram alguns estudos mais sistemáticos sobre a rede urbana do país (mormente os de Pedro Geiger e os associados ao IBGE), não obstante a carência de continuidade nesse âmbito temático.

2 - Nesse período encontravam-se seis cidades do Vale do Jequitinhonha classificadas como médias: Almenara, Araçuaí, Diamantina, Jequitinhonha, Pedra Azul e Salinas. Ver: Amorim Filho, O. B., Bueno, M. E. T. e Abreu, J. F. (1982).

3 - Na realidade o ouro foi descoberto na região central de Minas no último decênio do século XVII e o diamante na segunda década do século XVIII, na região do Tijuco, atual Diamantina.

4 - A idéia de "lugar urbano" deve remeter à noção de infra estrutura urbana bem como a de rede. Ambos os aspectos são fundamentais para que se possa levantar hipóteses sobre o maior ou menor significado da rede urbana do Vale do Jequitinhonha nos Séculos XVIII e XIX. A simples constatação de que um lugar foi primeiramente povoado não é suficiente para elevá-lo à categoria de "lugar urbano". Muitos destes lugares não atingiram níveis de infra estrutura e articulação espacial capazes de justificar a sua inclusão na categoria de "lugar urbano." 
escolhidas as fronteiras da Macrorregião de Planejamento VII de Minas Gerais. Temporalmente os limites deste trabalho encontram-se entre os séculos XVIII e fins do XIX, quando diversas mudanças políticas, econômicas e sociais configuraram uma nova etapa da história do país (Iglésias, 1970).

Pretende-se tratar, de maneira abrangente, do surgimento dos primeiros núcleos populacionais urbanos significativos da região, os lugares urbanos, tendo em vista a espacialidade que tais processos envolveram à época, uma vez que a configuração atual do Vale do Jequitinhonha é fruto desse processo histórico. As principais observações dirão respeito às atividades sócio-econômicas envolvidas, principalmente às atividade minerária e garimpeira, bem como a pecuária de corte, de caráter extensivo, todas importantes enquanto vetores das primeiras entradas na região e da sua posterior ocupação, sendo fundamentais para a compreensão da dinâmica de estruturação da rede urbana e do meio rural.

\section{A GENÊSE DA ESTRUTURA ESPACIAL}

Em 1693 os territórios do Rio de Janeiro, São Paulo e Minas Gerais constituíam uma única Capitania. Em 1709, o Rio de Janeiro é separado de São Paulo e Minas. Finalmente em 1720 a Capitania Real de Minas Gerais é separada de São Paulo. ${ }^{5}$ Os objetivos desta divisão administrativa estavam ligados à tentativa da Coroa de executar um controle mais efetivo sobre a região das minas. As revoltas de Vila Rica e Pitangui contra a cobrança do "quinto" no início do século XVIII, deixaram claro à Portugal esta necessidade (Paula, 1988:452-65).

\section{ENTRADAS E CAMINHOS}

A região do sertões, posteriormente denominada “das Minas”, já era muito conhecida dos Bandeirantes. Os diversos caminhos que davam acesso ao interior da Colônia eram trilhados periodicamente, seja em busca de nativos para serem escravizados, seja à procura de ouro e pedras preciosas. Embora o litoral tenha sido primeiramente ocupado, boa parte do interior vinha, concomitantemente, sendo progressivamente ocupada (Petrone, 1970:127-58). As atividades econômicas ponta de lança destes processos foram principalmente a cana de açúcar ${ }^{6}$ e o gado.

De fato, a pecuária bovina passara a representar um dos mais significativos vetores da ocupação do espaço brasileiro, ao penetrar lentamente no interior da Colônia. ${ }^{7}$ A ligação da pecuária com a indústria açucareira foi muita estreita. A expansão dos engenhos pelo litoral nordestino, vinha acompanhada da expansão da criação de gado "vacum", essencial para o fornecimento de couro, carne e animais de tração. A partir principalmente da Bahia e de Pernambuco, os currais foram se estendendo, tanto para o norte quanto para o sul. O rio São Francisco, neste sentido, teve um importante papel ao servir de aguada permanente, sendo as terras do seu grande vale uma importante fonte de $\mathrm{sal}^{8}$. Foi, sem dúvida, a estrada natural para o transporte do gado, facilitando a penetração para o interior, rumo às áreas à montante de seu curso. Assim, na última década do século XVI, a penetração da pecuária alcançava terras do sertão baiano e pouco depois atingia o norte de Minas Gerais. Com a mineração, no início do século XVIII, os espaços mineiros passam a ser efetivamente povoados.

Convém observar, conforme salienta Guimarães (1960:73), que os caminhos raramente eram feitos em áreas carentes de água, daí a preferencia pelos vales em detrimento das chapadas, que só foram utilizadas como caminho muito tempo depois. Os vales, além de serem rota segura contra os obstáculos do relevo, possuíam, com

\footnotetext{
5 - Embora hoje estas divisões espaciais pareçam mais claras, à época da Colônia e mesmo no Império, as superposições das divisões funcionais no espaço produziam uma precisão muito menor. Caio Prado quando se refere aos órgãos da administração geral e civil alertava que incluíam-se aí "tanto funções propriamente administrativas (em nossa terminologia moderna), como de justiça." (Prado Júnior, 1973:313). Estudando o período, Martins \& Paiva (1985:9) corroboram esta tese quando dizem: "Parece válido supor que, não havia em 1831, uma divisão político administrativa clara." Um resumo da divisão administrativa para a período colonial pode ser assim entendido: a maior unidade administrativa era a Capitania, sendo esta dividida em unidades judiciárias, as comarcas. Minas era dividida em três Comarcas em 1714: Vila Rica; Sabará - Rio das Velhas; São João del Rei - Rio das Mortes; passa a quatro Comarcas em 1720 com a criação da Comarca do Serro Frio; a cinco com a de Paracatu em 1815 e a seis com a de São Francisco em 1820. As Comarcas se dividiam em termos, com sedes nas vilas ou cidades; os termos se dividiam em freguesias (divisão eclesiástica que forma a paróquia mas que também servia à administração civil). As freguesias por seu turno se dividiam em bairros, de limite e caráter extremamente imprecisos. Ver: Prado Júnior (1973:306); Paula (1988: 58-65) e Carvalho (1922).

6 - A cana de açúcar, nativa da Índia, foi trazida pelos portugueses para o Brasil a partir das ilhas da Madeira, Canárias, Cabo Verde e São Tomé. Rapidamente a cultura expandiu-se, principalmente pelo litoral nordestino. Em meados do século XVII a Colônia tornou- se a maior produtora mundial de açúcar. Inúmeros engenhos foram estabelecidos durante os séculos XVI e XVII. Ver: Pereira (1977). 7 - A primeira remessa de gado bovino remonta à vinda da frota de Tomé de Souza, que chega à Colônia em 1549 trazendo entre outras coisas, algumas cabeças de gado. Em 1550 novo desembarque de bovinos. O então Governador-geral ordena a mesma caravela, a "Galga", a fazer novo carregamento do mesmo gado em Cabo Verde. Em 1552 já aparece a "Casa da Torre de Garcia D'Ávila”, grande sesmaria que a partir da Bahia, em Tatuapara, alcança o rio São Francisco através de Sergipe, ocupando grande parte do sertão baiano. Cf.Holanda \& Campos (1973:117, v.1) e Azevedo (1970: 379).

8 - "O sal é um dos productos naturaes mais interessantes do valle de São Francisco" (Sampaio, 1938:80). O sal existente nas suas "salinas", o famoso "sal gema", "lambedouros" dos bois, foi fator decisivo para expansão da pecuária nesta região e posteriormente no médio e baixo vale do rio Jequitinhonha, que também possui numerosas "salinas". Sobre este fato é interessante lembrar o monopólio do sal, que entre tantos outros afetou diretamente a economia da Colônia entre 1665 e 1795, ano em que uma carta régia de 27 de maio o extingue. Ver: Frieiro (1966:166); Prado Júnior (1973:54) e Guimarães (1960:63-9).
} 
freqüência, fontes de água perene, o que delineava o surgimentos de rotas que tendiam a se tornar permanentes.

O gado, percorrendo e emoldurando tais rotas, tornase então fundamental como suporte à vida daqueles que se aventuraram em busca do ouro (através dos fluxos procedentes da Bahia, e das área ao sul da Colônia). O consumo anual de carne no período da mineração implicava no abate de cerca de 18 a 20 mil bois/ano, havendo necessidade de fornecimento permanente, conseguido inicialmente através de contratos estabelecido pelo governo local com fornecedores de outras regiões ${ }^{9}$.

$\mathrm{Na}$ verdade a região de mineração encontrara nos muares, burros e mulas, os animais mais apropriados às atividades extrativas e mais adaptados aos difíceis caminhos da região. O transporte de cargas, inicialmente efetuado por escravos, passa posteriormente a ser feito por burros e mulas. Só muito depois as estradas tornamse "carroçáveis"10.

\section{ATIVIDADES ECONÔMICAS E REDE URBANA}

A espacialização é uma condição fundamental dos processos históricos. A dimensão sócio-espacial como eixo de reflexão é não só enriquecedora como também primordial para a compreensão desses processos, contribuindo para integrar novos elementos à pesquisa.

Inicialmente, convém observar que a História do Brasil sempre salientou a grande importância dos "ciclos econômicos" para estruturação do seu território. Hoje, à luz dos novos estudos, faz-se necessária uma revisão de alguns desses processos, entendidos como formadores quase únicos de nossa configuração geo-econômica.

A exportação, atividade à qual se encontram ligados esses "ciclos", sempre foi elemento fundamental da economia colonial. Mas exportar não era a única atividade econômica de peso na Colônia. Desde a descoberta do ouro, e posteriormente do diamante, ou mesmo um pouco antes, a produção e circulação de mercadorias não era desprezível ${ }^{11}$. Neste particular o Vale do Jequitinhonha apresenta características singulares: ocupado o seu território e vinculado à lógica da exportação de riquezas minerais, de alto valor e fácil contrabando, essa região, em face de sua localização e atributos geográficos, era uma das que despertavam suspeitas das autoridades coloniais. Outro aspecto notável que singulariza a Região diz respeito ao seu processo de urbanização e à proximidade com a Bahia.

A rede urbana que surge nesse período vai ser profundamente alterada no século seguinte. Os deslocamentos posteriores do eixo econômico, modificaram a dinâmica interurbana de Minas. Não é confirmado contudo, como parecia ser evidente em estudos anteriores, que a decadência se operou de imediato nas áreas centrais e nordestinas de Minas.

Alguns autores contemporâneos afirmam que a economia mineira setecentista e oitocentista, era razoavelmente mercantilizada e monetizada (Paula, 1988). Só assim se explicaria a grande aquisição de escravos e o expressivo comércio de exportação e importação com áreas do Rio de Janeiro, São Paulo e Bahia, mesmo após o ápice do período minerador (Paiva, 1996). Os fluxos de mercadorias justificariam uma estrutura urbana mais complexa e a existência de uma rede de lugares de certo destaque para a época.

Certamente, não obstante o declínio da mineração nas áreas centrais da Capitania, o período que se estende entre o final do século XVIII até a metade do século XIX é rico em um processo de diversificação econômica, inclusive à sul e nordeste, com a generalização mais efetiva da agropecuária, a continuidade do desenvolvimento comercial e a introdução de práticas agrícolas que preparariam o território para experiências mais significativas na segunda metade do século XIX. Além disso, ainda era forte a perspectiva de novos surtos de geração de riqueza derivada da mineração, tanto por parte da Coroa, quanto por parte dos milhares de indivíduos dispersos pelas cabeceiras dos córregos, os quais dominavam perfeitamente as técnicas mais usuais de extração de ouro e pedras preciosas. $\mathrm{Na}$ verdade, eram freqüentes ainda tais achados, o que despertava grande desconfiança da Coroa, a ponto de ter interditado durante muitos anos o acesso à Demarcação Diamantina.

A segunda metade do século XIX apresentou

9 - A qualidade do gado era, no entanto, pouco satisfatória. Apesar do seu importante papel no processo de ocupação do interior, como fonte de alimento e de tração, eram geralmente animais pequenos, de origem européia e pouco adaptados aos trópicos. Seu peso em carne alcançava cerca de 120 quilos e sua força como animal de tração era deficitária para a maioria dos trabalhos. Esta situação só irá melhorar muito mais tarde, a partir de fins do século XIX e início do XX, com a importação de reprodutores e matrizes de origem indiana (zebu e gir), mais adaptados ao tipo de clima, mais robustos e resistentes para o trabalho e de maior tamanho, tendo portanto mais peso na hora do abate. Ressalte-se que o gado bovino, muito empregado como animal de tração nas áreas litorâneas e mesmo em regiões mais descampadas e de relevo suave do interior da Colônia, não apresentava as mesmas vantagens quando utilizado em regiões de relevo movimentado e de difícil acesso. O maior interesse pelos bovinos nestas regiões devia-se ao seu emprego como fonte de alimento e fornecedor de couro, do qual eram feitas as "solas". A sua utilidade como animal de tração limitava-se a alguns serviços mais pesados. Ver inclusive Frieiro (1966: 203).

10 - Ver à propósito Azevedo (1970: 379-381) e Prado Júnior (1973: 254-257).

11 -Até a década de 60 muitas das análises publicadas sobre a história de Minas Gerais, principalmente sobre o período compreendido entre os séculos XVIII e XIX, situavam-na sob o signo dos grandes ciclos econômicos, considerando menores vários dos aspectos particulares da sua economia. $\mathrm{O}$ resultado foi a produção de trabalhos que não puderam identificar a rica dinâmica interna da região. A partir da década de 70 no entanto, surgem pesquisas que começam a definir com maior precisão esta dinâmica. A década de 80 é caracterizada pelo aparecimento da temática do mercado interno nos estudos de caráter histórico. Cf. Chaves (1995) e Meneses (1997). 
elementos novos e fundamentais que vieram afetar a estruturação da região, em face dos desdobramentos que tais mudanças globais produziram em favor de áreas meridionais do País e que resultaram na expansão sem precedentes da economia paulista. Entre tais elementos cabe destacar três: as alterações na estrutura da mão de obra com o fim da escravidão; o deslocamento do eixo dinâmico da economia nacional, da mineração para o café; e as alterações na política nacional, com o advento da República.

\section{O VALE DO JEQUITINHONHA E A EXPANSÃO DO CENTRO DE MINAS}

A região hoje conhecida como Vale do Jequitinhonha foi uma das primeiras a ser ocupada em Minas Gerais. Sua história remonta às primeiras Entradas e o ouro e as pedras preciosas tiveram primordial significado na estruturação de seu território.

Por meio das bandeiras seiscentistas, descobriu-se ouro na região do córrego do Tripuí, hoje Ouro Preto. ${ }^{12} \mathrm{~A}$ partir de então, diversas outras penetraram no território mineiro, dando início à efetiva ocupação do interior. Esta ocupação iniciada no séc. XVII e continuada durante todo o séc. XVIII, teve como principais vetores econômicos a extração mineral (na sua variante legal, a mineração, e na ilegal, o garimpo $)^{13}$ e a pecuária, esta muito significativa enquanto atividade permanente, que lenta mas constantemente ocupava o interior. A área central da Capitania e a região do Vale do Jequitinhonha, notadamente o Alto Jequitinhonha, passaram a partir de então a constituir importantes áreas de atração de população. Tudo isso viria estimular a urbanização visà-vis o desenvolvimento de uma economia gradativamente voltada para o mercado interno. ${ }^{14}$

"Nenhuma atividade econômica teve (...) maior influência na criação e no desenvolvimento das cidades do interior e, portanto, na produção do fenômeno urbano do que a indústria mineradora, não só na região das "minas gerais", como, pelas suas repercussões, sobre o centro comercial e político que deslocou para o Rio de Janeiro."(Fernandes, 1975:144).

Os caminhos para as Minas, importantes elos de conexão com a rede urbana em formação, inicialmente trilhados pelas bandeiras e posteriormente muito utilizadas quando da mineração, resumiam-se a três: o de São Paulo (caminho velho); o do Rio de Janeiro (caminho novo); e o da Bahia, também antigo e que apresentava duas variantes, uma pelo Vale do São Francisco e outra, pelo rio Gavião em direção ao atual município de Rio Pardo. ${ }^{15}$

O surgimento de uma rede de lugares urbanos na região central de Minas como também no Alto Vale do Jequitinhonha vinculou-se, de outra parte, à necessidade de um controle mais efetivo das áreas mineradoras. ${ }^{16}$

"Ao contrário do que se dá na agricultura e em outras atividades da Colônia, a mineração foi submetida desde o início a um regime especial de minuciosa e rigorosa disciplina."(Prado Júnior, 1973:174).

Isto levou à criação de 16 vilas e do Distrito Diamantino ${ }^{17}$ durante o período colonial, sendo 14 ainda no século XVIII. A finalidade destas vilas era fundamentalmente impor ordem à desordem que se configurava em diversos povoados e, naturalmente, recolher os tributos. Duas localidades foram de fundamental importância nesse sentido: Ouro Preto, na área central, e Serro, a nordeste. Ambas surgiram no período compreendido entre o fim do séc. XVII e início do XVIII como fruto da busca por minerais preciosos.

Vila Rica, atual Ouro Preto, foi uma das três primeiras vilas criadas nas Minas Gerais no ano de 1711. As outras duas seriam a do Ribeirão do Carmo, atual Mariana, única "Cidade" mineira do período colonial e a Vila Real de Nossa Senhora da Conceição de Sabará, hoje Sabará ${ }^{18}$. Mais próxima do Rio de Janeiro, Vila Rica, cujo crescimento tornara-se muito expressivo, viria se tornar capital da Capitania em 1721.

Serro, por outro lado (elevado à Vila do Príncipe e cabeça de Comarca em 1714) ${ }^{19}$, localizada na Serra do Espinhaço, no Alto Vale do Jequitinhonha, tinha o seu acesso dificultado pelo relevo movimentado e grande distância em relação à região central da Capitania. A dificuldade de integração com o centro das Minas também associava-se ao interesse único da Coroa portuguesa na exploração de forma predatória, sem

12 - É importante observar que o ouro e mesmo o diamante, entre outros metais preciosos e gemas, já haviam sido descobertos na Colônia antes deste período e em outras áreas. A sua exploração contudo não era significativa devido a diversos fatores de ordem natural e mesmo outros como os de ordem econômica, administrativa e tecnológica. Cf. Holanda \& Campos (1973: 228-58, v.2.).

13 - O termo garimpeiro tem origem na palavra "grimpa" que quer designar "o ponto mais alto; cocuruto, crista" do relevo, onde estes trabalhadores clandestinos escondiam-se quando perseguidos, devido ao caráter ilegal da sua atividade. Cf. Santos (1976:77) e Salomão (1984:42).

14 - Caio Prado define a área de maior adensamento populacional à época em Minas como sendo aquela localizada "numa faixa que se estende de sul a norte, da bacia do rio Grande às proximidades das nascentes do Jequitinhonha, mais ou menos entre os pontos em que se formam a vila de Lavras e o arraial do Tejuco" (Prado Júnior 1973: 57).

15 - Conforme observam Antonil (1711) em sua "Cultura e opulencia do Brazil por suas drogas e minas"; Prado Júnior (1973:243-5) e Paula (1988:127-132).

16 - Sobre estes aspectos a leitura da conhecida obra "Memórias do Distrito Diamantino" de Joaquim Felício do Santos é esclarecedora. 17 - É importante notar que a relevância do povoado na rede pode não estar diretamente relacionada à sua posição na hierarquia jurídico-administrativa existente, embora esta posição seja um indicador da sua maior complexidade no que se refere aos serviços administrativos. Assim, o Tejuco (Diamantina), premido pelo Regimento da Demarcação Diamantina, continuou arraial durante todo o período colonial, sendo elevado a vila em 1831. “Com a criação do Distrito Diamantino, o Tejuco continuou arraial, e o Serro foi uma espécie de capital daquela área" (Paula 1988: 56-57).

18 - Ver: Paula (1988: 55-65) e Costa (1970: 16-21).

19 - Esta data é polêmica. Teophilo Feu de Carvalho discorda francamente dela estabelecendo o ano de 1720 como o da criação da Comarca do Serro Frio e da Vila do Príncipe (Serro). Carvalho (1922: 21-42). 
cogitar da criação de estruturas capazes de sustentar posteriormente um desenvolvimento sócio-econômico mais consistente. Ao contrário, a manutenção de redes de acesso precárias e a obscuridade das rotas e da estrutura interna da região dos diamantes, parecia encontrar na política da metrópole todo o apoio.

Contudo, apesar dessas adversidades, surgiram alguns núcleos populacionais de importância. A estruturação de uma rede de lugares no alto vale do rio Jequitinhonha, que se configurava como periférica à da região central, veio se mostrar bem articulada internamente e integrada a outras localidades fora da região. As trocas comerciais, entre as localidades e o litoral, extremamente lucrativas para os tropeiros e comerciantes, mantiveram-se não obstante as interdições da Metrópole. A coroa entendia, por razões óbvias, ser o comércio um dos principais meios nos quais se processava o contrabando. Outro fator fundamental para esta continuidade estava relacionado aos preços alcançados pelos produtos na região das Minas, muito superiores aos praticados nas outras áreas da Colônia, tendo no ouro em pó a sua moeda corrente.

A historiografia recente tem contestado alguns estudos anteriores que postulavam uma falta de dinamismo próprio da região que não contassem com o ouro e os diamantes. Hoje sabe-se que apesar da fundamental importância destas riquezas para a estruturação do Vale do Jequitinhonha, não seria possível compreende-lo sem levar em consideração a agricultura e a pecuária, inicialmente voltadas para a subsistência mas posteriormente engajadas num circuito comercial que visava o mercado interno e mesmo o externo ao Vale.

Apesar das grandes dificuldades impostas pelo meio geográfico, como o relevo e as duras condições climáticas e as de natureza econômico-social, a região conseguiu estruturar-se em uma rede de lugares significativa no contexto da Capitania. Esta rede, em grande medida ainda presente na atualidade, sofreu ao longo da história significativas mudanças. Algumas localidades, inicialmente importantes, hoje são apenas coadjuvantes na rede urbana; outras surgiram ou ressurgiram mais recentemente, envolvidas em distintas dinâmicas econômicas como a pecuária, o café, a aguardente e até mesmo o turismo; algumas no entanto permaneceram em lugar de destaque durante toda a história da região, embora nem sempre tenham se mantido fiéis às mesmas atividades econômicas predominantes quando do seu surgimento ${ }^{20}$.

\section{A REDE DE LUGARES URBANOS DO VALE DO JEQUITINHONHA}

\section{ASPECTOS METODOLÓGICOS}

A análise subsequente foi empreendida a partir de consultas a documentos e mapas históricos tais como: o trabalho de Teophilo Feu (Carvalho, 1922); o manuscrito de José Joaquim da Rocha de 1781, Geografia Histórica da Capitania de Minas Gerais, reeditado na Coleção Mineiriana em 1995; as tabelas sobre estimativas populacionais cedidas por Clotilde Paiva (Paiva, mimeo,1997); o censo demográfico de 1872; o trabalho de Maria C. S. Martins (Martins, mímeo, 1997); os dicionários histórico-geográfico e toponímico escritos por Barbosa (1971) e Costa (1970); o mapa relativo ao início do século XIX de Carrato (1968); o tratado de geografia descritiva de José J. Silva de 1877, reeditado pela Coleção Mineiriana em 1997; outros mapas antigos editados nos séculos XIX e XX, a exemplo de Soares (1925); e sucessivas visitas de reconhecimento de campo feitas à região em estudo.

Trata-se de uma primeira tentativa exploratória de construir cartogramas e mapas temáticos que absorvam informações dispersas em diferentes fontes documentais mediante a utilização de recursos modernos de geoprocessamento. As informações espacializadas visam trazer maior clareza, para os estudiosos e público em geral, sobre importantes fatos geoeconômicos que pertencem a história da formação de nossa rede de lugares. Por essa razão privilegia-se sempre a inserção dos nomes dos povoados e lugares urbanos nos cartogramas segundo a denominação atual, deixando as denominações antigas em quadro anexo (Quadro 1) no corpo do texto, da mesma forma que utiliza-se simplificadamente de segmentos de reta como recurso para mostrar tão somente as articulações entre as localidades, como se representassem a estrutura de caminhos da região.

A consulta a documentos relativos a história administrativa de Minas foi útil para o conhecimento de uma espécie de hierarquização existente entre as localidades. Ao se adicionar a verificação de trilhas, caminhos e estradas existentes, no período em análise, foi possível estabelecer por dedução, como resultado, as categorias de lugares urbanos mais importantes e menos importantes (constantes das legendas dos Mapas $1,2$ e 3$)$.

A definição de lugar urbano foi, sem dúvida, uma das mais difíceis, em face não só das definições oficiais de Cidade e Vila, inadequadas à realidade dos fatos urbanos em Minas Gerais, mas também dos casos obscuros em que determinados povoados e arraiais situavam-se na condição de distritos, freguesias e termos sem contar, todavia, com o mínimo de equipamentos que pudessem qualificar uma localidade urbana. A justificativa mais detalhada da presença de cada uma das localidades na rede aqui apresentada vem sendo elaborada em outro trabalho ${ }^{21}$. Resumidamente, os lugares urbanos envolvem a presença: de casario aglomerado em pequena área física; arruamento (ainda que mínimo); equipamentos relacionados à gestão territorial (como instituições administrativas, coletorias, postos de vigilância); comércio de mercadorias e eventuais sistemas de transportes. A consulta à rede de

20 - Sobre as cidades brasileiras convém mencionar o texto "As cidades" in: Azevedo (1970: 211-282).

21 - No interior dos documentos que compõem a pesquisa em andamento, financiada pela FINEP, intitulada "Reestruturação sócioespacial e desenvolvimento regional do Vale do Jequitinhonha”. 


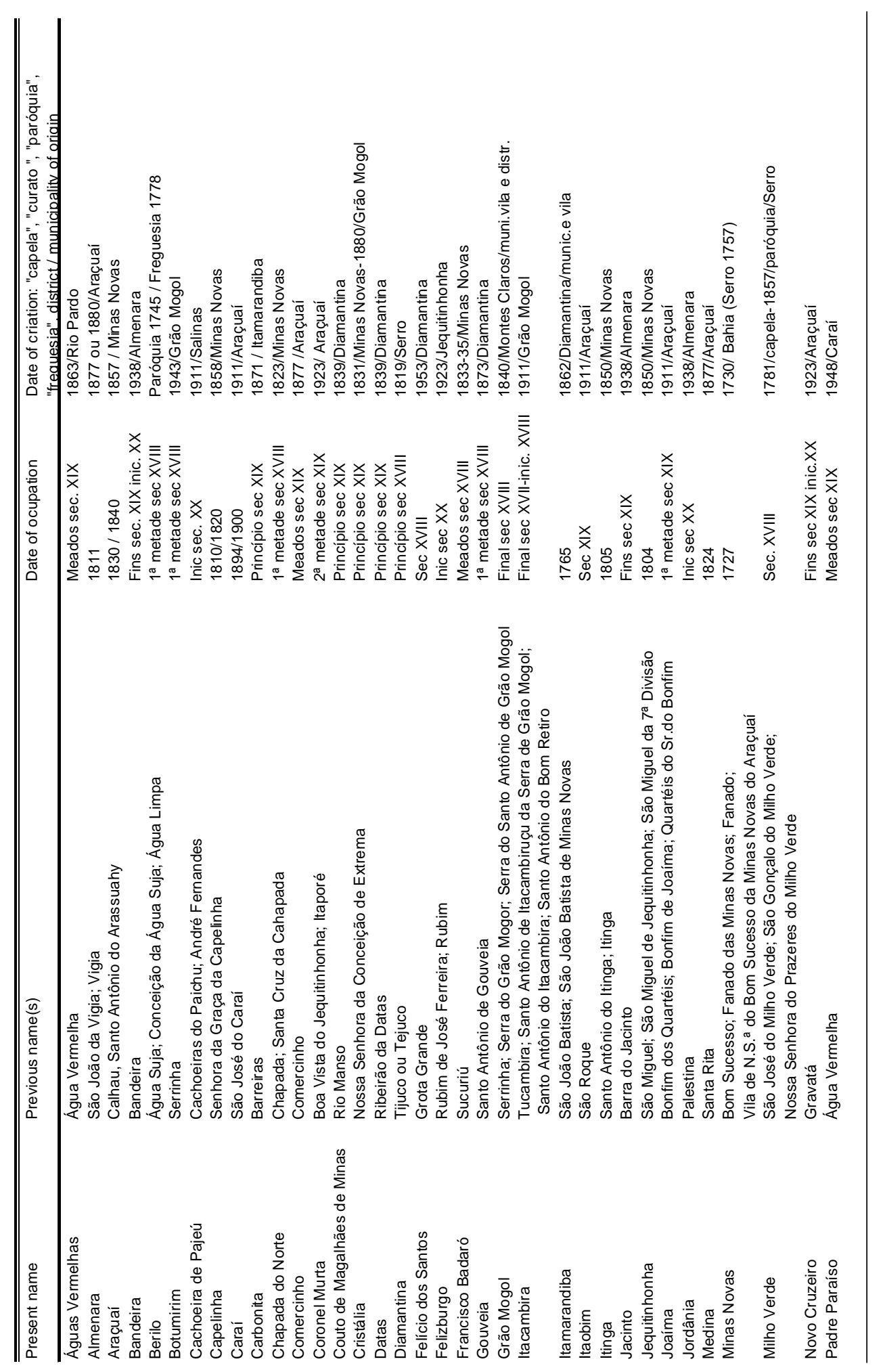



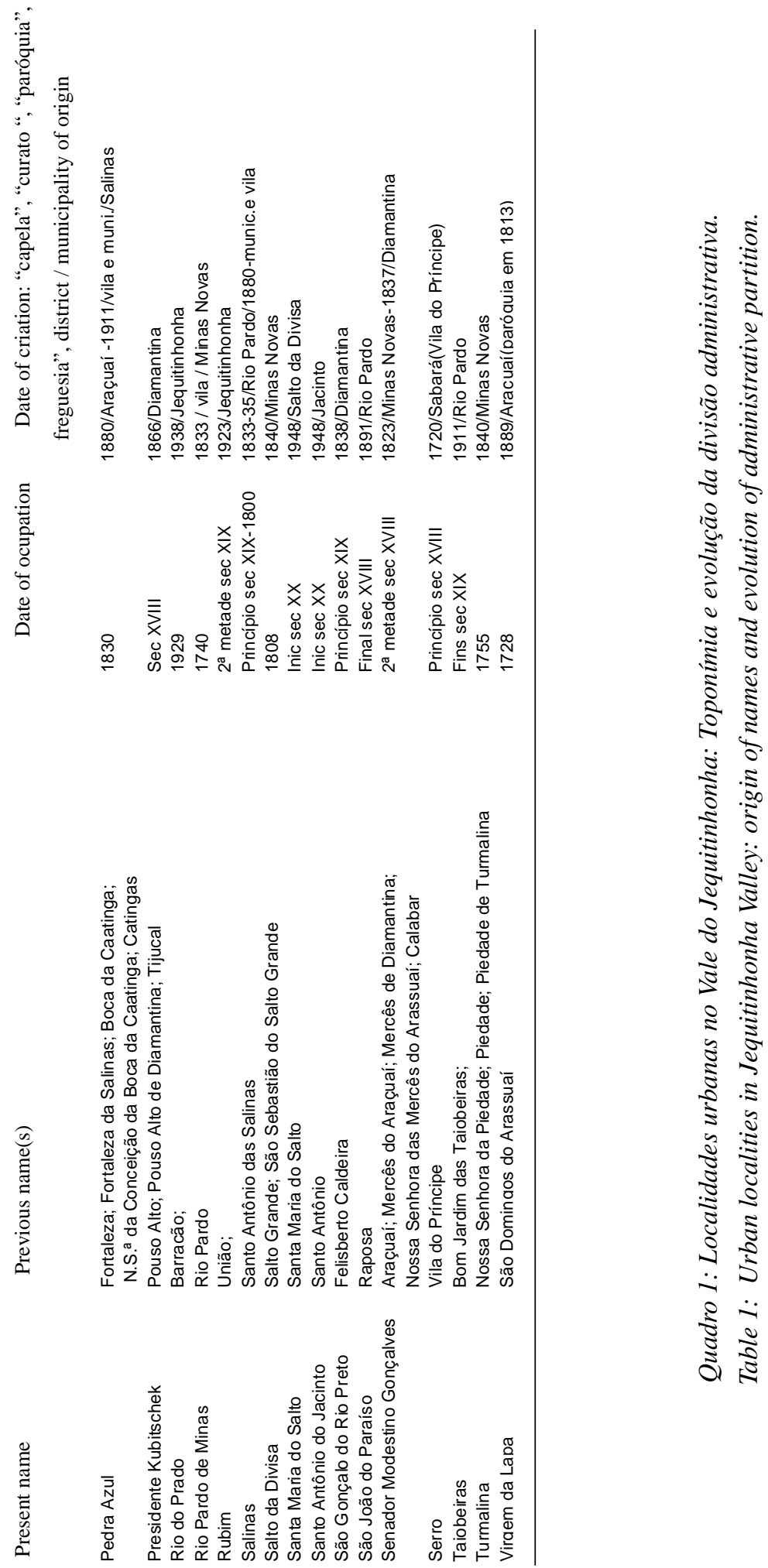
caminhos foi o recurso utilizado para a dissolução de algumas dúvidas com relação a definição e hierarquia desses lugares.

Com relação ao tamanho das populações urbanas, as consultas aos dados de Clotilde Paiva e aos dados do censo de1872, foram importantes como meio de se estabelecer os pontos da rede. Contudo, cabe salientar que tais populações eram freqüentemente muito pouco expressivas ao se considerar os tamanhos populacionais de nossas cidades na atualidade. Examinar esta questão com os olhos da época é sempre um desafio. Contudo, ainda recentemente, é bom lembrar, a própria definição do IBGE de lugar urbano é suscetível de controvérsias, já que, por exemplo, em 1958, na Enciclopédia dos Municípios, eram definidas como urbanas as localidades que reuniam mais de 500 pessoas residindo nas sedes municipais.

\section{A FORMAÇÃO E DESENVOLVIMENTO DA REDE DE LUGARES URBANOS}

Os lugares urbanos mais importantes do Vale do Jequitinhonha que vieram se consolidar no século XVIII (ver Mapa 1) foram: Serro, Cabeça da Comarca do Serro Frio em 1720 (Carvalho,1922:21-58); Diamantina (antigo Tijuco, arraial pertencente à Vila do Príncipe e elevado a vila em 1831), primeiro lugar onde foram descobertos diamantes, centro administrativo da Intendência dos Diamantes da Demarcação Diamantina (Santos,1976:45-57); Barbosa,1971:162-63); e Minas Novas, arraial elevado à vila em 1729, judicialmente pertencente à Comarca do Serro Frio, mas administrativa e militarmente fazendo parte da Comarca da Bahia até $1757^{22}$. Estes três lugares constituíram os principais pontos da rede urbana que se esboçava, quer pelo caráter administrativo que possuíam, quer pela expressão das suas lavras minerais, quer pelo significativo contingente populacional que utilizava-se de tais localidades como referência comercial e de abastecimento.

Araçuai, Berilo, Itacambira e Rio Pardo podem ser considerados como lugares urbanos de menor importância, embora funcionassem como pontos de ligação da rede com áreas mais distantes, internas ou externas ao vale do Jequitinhonha. Berilo, um dos arraiais que surgiu nas proximidades de Minas Novas, "prosperou e foi elevado à freguesia" (Barbosa,1971:70). Itacambira, situada numa região de ocupação antiga, cujo processo de exploração mineral iniciou-se por volta de 1698 (Barbosa,1971:224-25), era um dos principais pontos das rotas do comércio regional e interregional. Ligava-se ao registro de Inhacica, por onde passavam passageiros e mercadorias vindas de povoações da margem direita do rio São Francisco (Chaves, 1995:117). Rio Pardo, freguesia criada em 1740, tornou-se próspera (Barbosa,1971: 409-10), servindo como importante ponto de ligação entre o vale do Jequitinhonha e o sudoeste baiano (Rocha,1995; Carrato, 1968).

O Mapa 1 explicita ainda a importância de três articulações que integravam a rede urbana em formação: a que ligava Diamantina e Serro com o centro de Minas; a que ligava Diamantina e Itacambira, e daí com o vale do São Francisco; e a que ligava Rio Pardo com o São Francisco (já na Bahia) e o sudoeste baiano pelas bacias dos rios Pardo e Gavião.

Até 1730, das nove vilas criadas em Minas, duas estavam na Comarca do Serro (Serro e Minas Novas). O número dos "registros" e a circulação de mercadorias indicam uma situação dinâmica em termos de trocas de mercadorias e fluxo de pessoas (Chaves,1995; Meneses, 1997 e Paula,1988). Assim, a materialização de uma rede urbana associada ao extrativismo mineral e ao comércio no interior do Espinhaço (Serro, Diamantina, Itacambira, Minas Novas, Berilo e Rio Pardo) constitui uma característica singular que tipifica a rede urbana do Vale do Jequitinhonha em relação a outras áreas da Capitania que vieram conformar redes urbanas. As dificuldades naturais de acesso, acrescidas às restrições impostas pela Demarcação Diamantina, não foram capazes de impedir o surgimento de um comércio significativo, que alicerçado na atividade mineradora começou a estruturar a rede de lugares urbanos.

\section{A FRENTE BAIANA, A REDE DE CAMINHOS E A REDE URBANA}

A presença baiana no Jequitinhonha, desde o século XVIII, pode ser comprovada pelo menos pelas seguintes evidências: a) participação expressiva de baianos na guerra dos Emboabas, cujo palco de conflitos estendeuse por diversas áreas das "Minas Gerais"; b) a existência de caminhos naturais, de fácil circulação (vales fluviais amplos), que ligavam diferentes localidades do Jequitinhonha à parte baiana dos vales do São Francisco e Pardo; c) a maior antigüidade da economia baiana, que veio propiciar a geração de conhecimentos sobre o território (envolvendo o sertão e as áreas de matas ocupadas por tribos indígenas) e sobre atividades necessárias a sobrevivência (pecuária, agricultura e extrativismo) em áreas inóspitas da Colônia.

Os obstáculos à penetração das frentes de ocupação, vale dizer, eram de diversos tipos. Certamente a presença da mata Atlântica existente na Bahia e em áreas mineiras foi um deles. Inicialmente as áreas escolhidas para a criação do gado eram os campos, naturalmente mais "limpos", como em algumas regiões no vale do São Francisco. No sertão baiano, a carência de rios perenes que pudessem garantir o suprimento de água e o relevo constituído pelo Complexo do Espinhaço foram outros óbices dignos de nota. Correlatamente, a precariedades das comunicações e os conflitos entre 


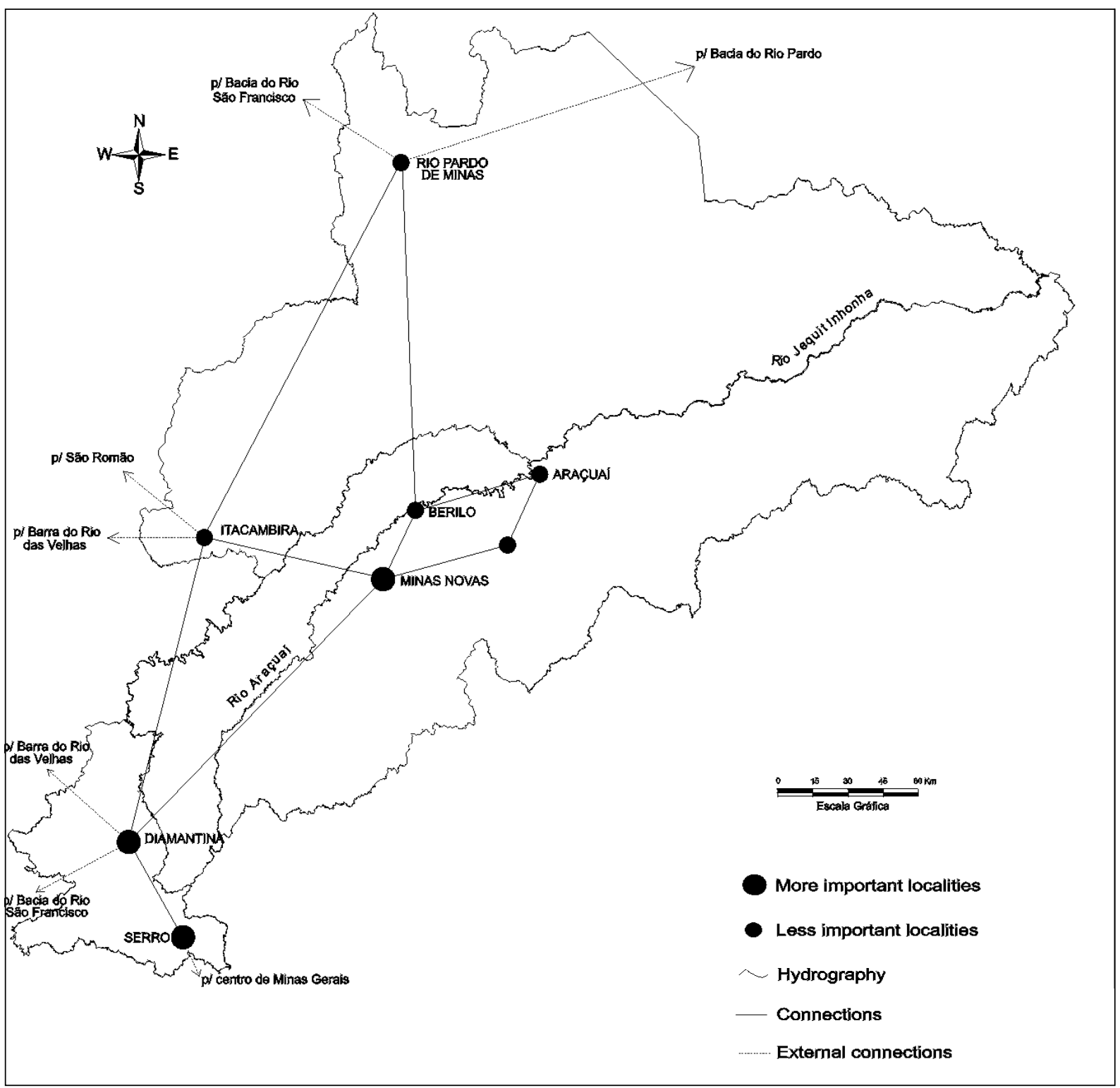

Mapa 1: Rede de localidades urbanas no Vale do Jequitinhonha no final do século XVII. Map 1: Network of urban localities in Jequitinhonha Valley by the late 18 th century. 
brancos e índios ${ }^{23}$, permeavam os amplos espaços de penetração e articulação entre o vale do Jequitinhonha, o centro mineiro e o sul-sudoeste da Bahia. A favor da ocupação da Região do Jequitinhonha e da penetração baiana pesou a condição de perenidade de seus rios, se comparados aos da Bahia.

A rede de caminhos ${ }^{24}$ que veio se estruturar ao longo dos vales fluviais foi, sem dúvida, um dos principais fatores que permitiriam a expansão da pecuária originária do Nordeste. Rios como o Jequitinhonha e o Pardo eram amplamente utilizados como vias de acesso do gado para nordeste de Minas (ver Mapa 1).

Além disso, convém ressaltar que o contrabando, responsável pela abertura de caminhos das Minas para outras regiões da Capitania, processava-se de maneira intensa pelos rios (a exemplo do rio São Francisco), pois estes apresentavam grandes dificuldades de fiscalização. Entre estas dificuldades é possível destacar aquelas que relacionam-se ao silêncio deste tipo de transporte, bem como à rapidez e pouca necessidade de víveres para se fazer a jornada (que podia ser executada por apenas 2 ou 3 pessoas comandando uma canoa). Embora o estabelecimento de Quartéis às margens destes cursos d'água pudesse ser relativamente eficiente (sendo levada a cabo a partir do século XIX), a construção e o funcionamento dos mesmos era uma tarefa difícil devido às distâncias dos centros de abastecimento e a obscuridade dos acessos. Em que pese todos estes aspectos, o estabelecimento destes Quartéis e a posterior liberação da navegação do rio Jequitinhonha, foram importantes vetores de ocupação da área e do estabelecimento da sua rede de lugares urbanos.

Na primeira metade do século XIX, a expansão da rede de lugares urbanos (Mapa 2), associa-se primordialmente à consolidação de pequenos núcleos garimpeiros que começaram a surgir ainda no século XVIII. As proibições do Regimento Diamantino eram severas e a perseguição aos garimpeiros dentro das áreas da "Demarcação" imprimia à atividade grandes riscos. Some-se as estes fatores, a relativa carência de ouro e diamantes, que começou a se esboçar na segunda metade do século e que tornou ainda mais penoso e ingrato o trabalho nas lavras. A procura de outras áreas, distantes dos lugares mais fiscalizados ou mesmo fora da área demarcada, resultou num movimento de parte da população, concentrada no alto Vale do Jequitinhonha, em direção a outras áreas, notadamente aquelas localizadas nas proximidades de Minas $\operatorname{Novas}^{25}$ e ao longo do médio Jequitinhonha. Alguns dos pequenos aglomerados que surgiram, após adquirirem uma maior consistência populacional e urbana, passaram a integrar a rede que começou a se esboçar no século XVIII. Com o relaxamento do Regimento Diamantino, estes lugares integrar-se-iam mais facilmente à rede urbana que emergia. O comércio que vinha se consolidando durante o século XVIII, passa a representar no século XIX uma importante atividade econômica. Os lugares urbanos surgidos desta expansão espacial, terão portanto na atividade comercial um importante complemento à mineração e ao garimpo. $\mathrm{O}$ abastecimento interno, em grande parte suprido pelos produtores da região desde meados do século XVIII, imprime um significativo movimento aos caminhos existentes forçando a abertura de novas rotas.

Pode-se concluir que, de fato, comércio e o contrabando, foram importantes para a indicação dos vetores de ocupação no Vale do Jequitinhonha. Além dos caminhos para o Rio de Janeiro e São Paulo, havia a rota, muito utilizada, do São Francisco. De outra parte, se constituía outra rota de contrabando, por via fluvial ligando o alto Jequitinhonha a Belmonte (BA) ${ }^{26}$. As proibições régias dos caminhos que levavam às Minas sinalizam para a importância do transporte fluvial, ainda no século XVIII. Com o relaxamento das restrições impostas ao Distrito Diamantino e a liberação da navegação pelo Jequitinhonha ${ }^{27}$, a ocupação e povoamento da porção média e baixa da Região ganhou forte impulso. Ademais, viabilizava-se o acesso a jazidas minerais ainda não devidamente exploradas, ou exploradas ilegalmente, o que vinha ao encontro dos interesses tributários da Coroa.

\section{A EXPANSÃO DA REDE NO SÉCULO XIX}

O Mapa 2 ao buscar evidenciar a rede urbana do Vale do Jequitinhonha em meados do século XIX expõe a notável expansão dos lugares urbanos, mormente através do reforço da rede de caminhos que já se

23 - Algumas tribos autóctones da região, genericamente denominadas de "Botocudos", eram reconhecidas pelos portugueses como constituída por povos bravios e avessos ao contato.

24 - Convém observar que os caminhos eram ainda incipientes, não carroçáveis, apenas para uso de pessoas e animais (gado bovino, asininos e muares). Todavia, sua utilização em termos de comércio interno e externo tornar-se-ia frequiente, como demonstram recentes estudos relativos a abastecimento, pautados nas pesquisas sobre "registros" e postos fiscais. Chaves (1995) e Meneses (1997).

25 - Ainda no século XVIII a região de Minas Novas tornou-se um centro garimpeiro, além de produtora de alimentos e entreposto comercial, dividindo então com o alto Jequitinhonha a polarização do Vale.

26 - Sabe-se que tribos indígenas da região eram exímias na arte de construir e manobrar canoas pelo rio. Essas técnicas foram apropriadas pelos exploradores "brancos", que as utilizaram por muito tempo (até a década de 1960).

27 - Em que pese o relativo desconhecimento do médio e baixo cursos do rio Jequitinhonha, tudo indica que técnicas de navegação e construção de embarcações já eram utilizadas, ainda que esporadicamente, durante o século XVIII. Belmonte, na foz do rio Jequitinhonha, que tornar-se-ia um importante porto, foi elevada a vila em 1764. Mas somente a partir de 1804, quando o Capitão Mor de Porto Seguro, João da Silva Santos sobe o rio a partir da sua embocadura, na Bahia, é que a sua navegação foi liberada. Sol (1981: 15) e Santiago 


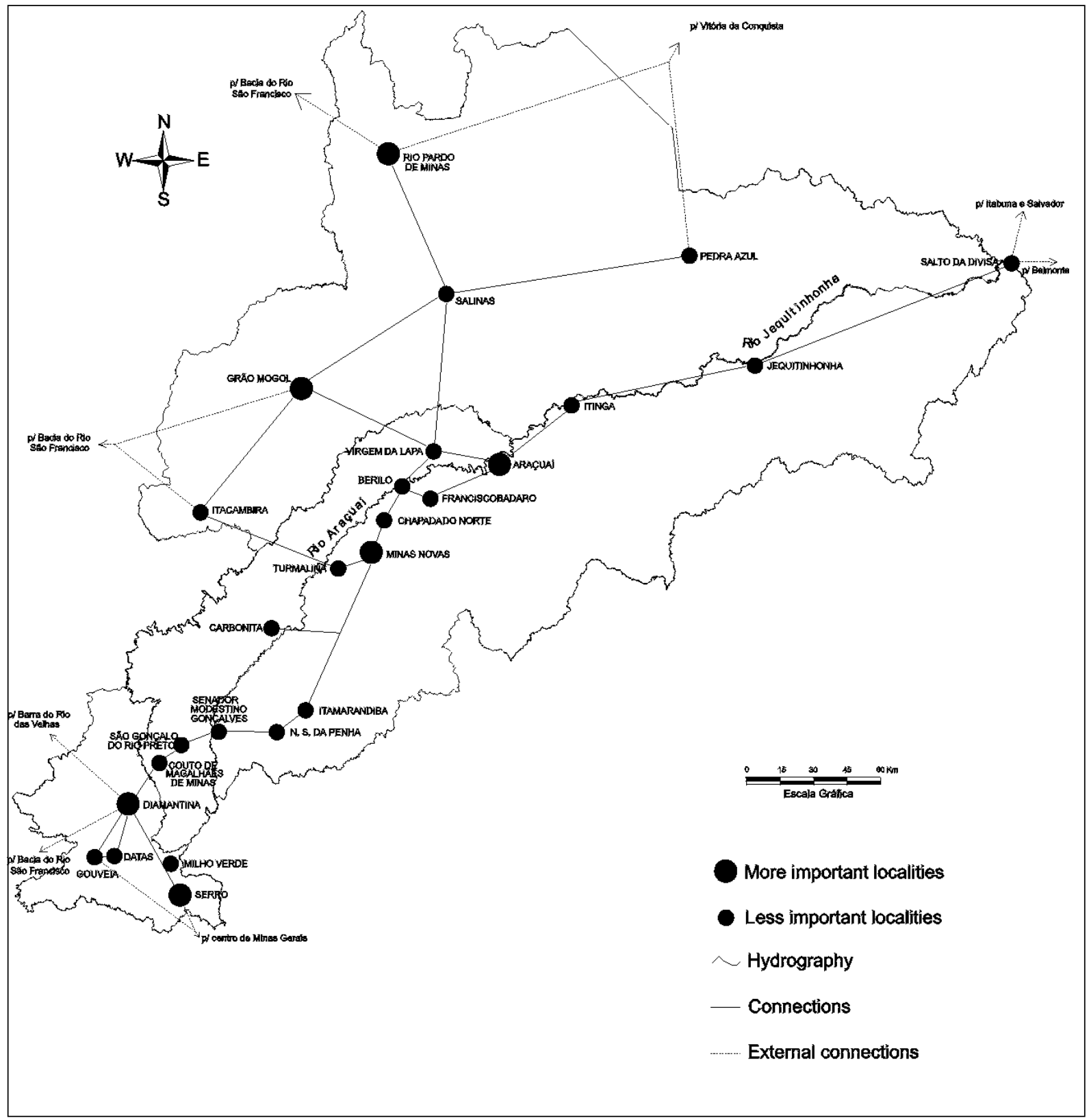

Mapa 2: Rede de localidades urbanas no Vale de Jequitinhonha em meados do século XIX.

Map 2: Network of urban localities in Jequitinhonha Valley by the middle 19th century. 
esboçava no Mapa 1. Fazendas, capelas e povoados já existentes no século XVIII, localizados em pontos estratégicos da rede de caminhos ganharam desenvoltura assumindo a condição de lugares urbanos ${ }^{28}$. Além disso, ganham expressão as articulações entre localidades postadas ao longo do rio Jequitinhonha em direção à Belmonte, foz do rio no sul da Bahia.

Entre o Alto e o Médio Jequitinhonha várias localidades vieram se desenvolver ao longo do caminho entre Diamantina e Minas Novas, estruturando um subconjunto de lugares urbanos nas proximidades da confluência do rio Jequitinhonha com o rio Araçuaí, no médio curso do Jequitinhonha. Entre estes lugares urbanos, considerados de primeira ordem, emergiam: Nossa Senhora da Penha, Itamarandiba, Turmalina e Chapada do Norte, todos tendo na mineração sua principal atividade econômica. No Alto Jequitinhonha, Diamantina, Serro e Gouvêia se destacavam, deixando Milho Verde em posição secundária, juntamente com Datas.

Além destes lugares, outros surgiam e/ou se afirmavam na porção norte do Vale do Jequitinhonha, embora Rio Pardo e Grão Mogol ainda mantivessem maior expressão demográfica que Salinas e Itacambira.

No médio-baixo Jequitinhonha Araçuaí, Jequitinhonha e Salto da Divisa (nomes atuais) já exibiam uma posição importante na rede urbana de meados do século XIX, não obstante a precariedade das comunicações por terra. Outros pequenos povoados já existentes, mas não constantes do Mapa 2, sinalizavam para o sentido da expansão da ocupação territorial que viria, pouco depois, reformatar a rede de lugares urbanos dessa porção regional. Exemplos dignos de nota são, certamente, os povoados de Pedra Azul, Águas Vermelhas, São João do Paraíso, Medina e Comercinho, já entrecortados de velhos caminhos ligados à Bahia, de onde vinham migrantes (especialmente de Vitória da Conquista e arredores) à procura de terras adequadas à agropecuária (algodão, cana e pecuária), conforme sugere o mapa de Rocha (1995).

A sul do médio-baixo Jequitinhonha, a presença de grandes extensões de florestas da Mata Atlântica, onde se localizavam tribos indígenas (Botocudos) constituía ainda um obstáculo de difícil transposição, conquanto já existissem incursões ocupacionais que viriam, a partir da segunda metade do século XIX, desalojar os indígenas, liquidar com a floresta e pulverizar a rede urbana em direção ao que se esboçava ser, em breve, Philadelphia, atual Teófilo Otoni.

O Mapa 3 exibe a conformação mais provável do que deve ter sido a rede urbana da Região em fins do século XIX. De fato, o avanço do processo de urbanização foi importante, apesar de variar com a dinâmica oscilante das relações econômicas que vieram caracterizar as novas áreas incorporadas à rede.

No médio e baixo Jequitinhonha foi notável a expansão da pecuária a partir da instalação de fazendas por baianos, portugueses e mineiros, os quais beneficiaram-se de condições naturais favoráveis à formação de pastagens e expansão da pecuária de corte, além da presença de um comércio dinâmico ao longo do rio Jequitinhonha e da proximidade com o tradicional mercado de consumo baiano.

Nesse sentido, Araçuaí, Jequitinhonha, Pedra Azul e Salto da Divisa comparecem na rede de lugares como áreas de importância estratégica, em face da função que passaram a desempenhar na pecuária de corte e no florescente comércio entre Minas e Bahia envolvendo gêneros alimentícios e tecidos, entre outros produtos.

Mais ao norte o caminho que unia Rio Pardo, Salinas e Virgem da Lapa ao resto da rede explicitava outro eixo estruturador articulado a Araçuaí e Minas Novas, favorecendo a consolidação destes lugares como nódulos de expressão econômico-espacial, por onde circulavam pessoas e mercadorias ${ }^{29}$. De outra parte, Grão Mogol (e Cristália) perdia expressão enquanto Itacambira caminhava para a mesma tendência, provavelmente devido aos acessos difíceis a estas localidades e à posição deslocada em relação aos eixos de circulação mais dinâmicos que emergiam.

Ao sul, evoluíam as articulações com os vales dos rios Doce e Mucuri, como resultado de processos econômicos de ocupação do leste mineiro. Os empreendimentos centralizados em Philadelphia e o avanço da criação de gado ${ }^{30}$ foram decisivos para a articulação entre tais regiões naturais. Isto permitiria, mais tarde no século XX, a materialização do caminho que viria sediar importante trecho da Rio-Bahia, e a

28 - Cabe repetir que a seleção destes lugares urbanos foi feita com base, entre outros aspectos, nos tamanhos populacionais dos termos elou freguesias (dados de 1831-35 e de 1872), consulta a documentos históricos e pesquisas nos municípios, mas sempre considerando que o tamanho urbano deve ser referido aos padrões de tamanho das cidades à época. De qualquer maneira, ao se imputar a condição urbana procurou-se não discrepar em muito da definição oficial de paróquia (ou freguesia) que requeria a presença de 8.000 “almas” na localidade (nas áreas rurais e urbanas). Em geral, freguesias e termos que abrigavam essa população possuíam um núcleo urbano de expressão. O corte de tamanho populacional mínimo aqui utilizado girou em torno de 4.000 pessoas para o período de 1831-35 e 6.000 pessoas para 1872.

29 - A literatura registra para o período um importante movimento econômico entre lugares postados ao longo do rio Jequitinhonha, a partir de um rico comércio feito por canoas articulando o sul da Bahia e Minas Gerais, favorecendo expressivamente Araçuaí, Salto da Divisa, Jequitinhonha e outras localidades ribeirinhas.

30 - Esse processo foi mais característico das primeiras décadas do século XX, quando terras de excelente qualidade ficaram disponíveis, após retirada 


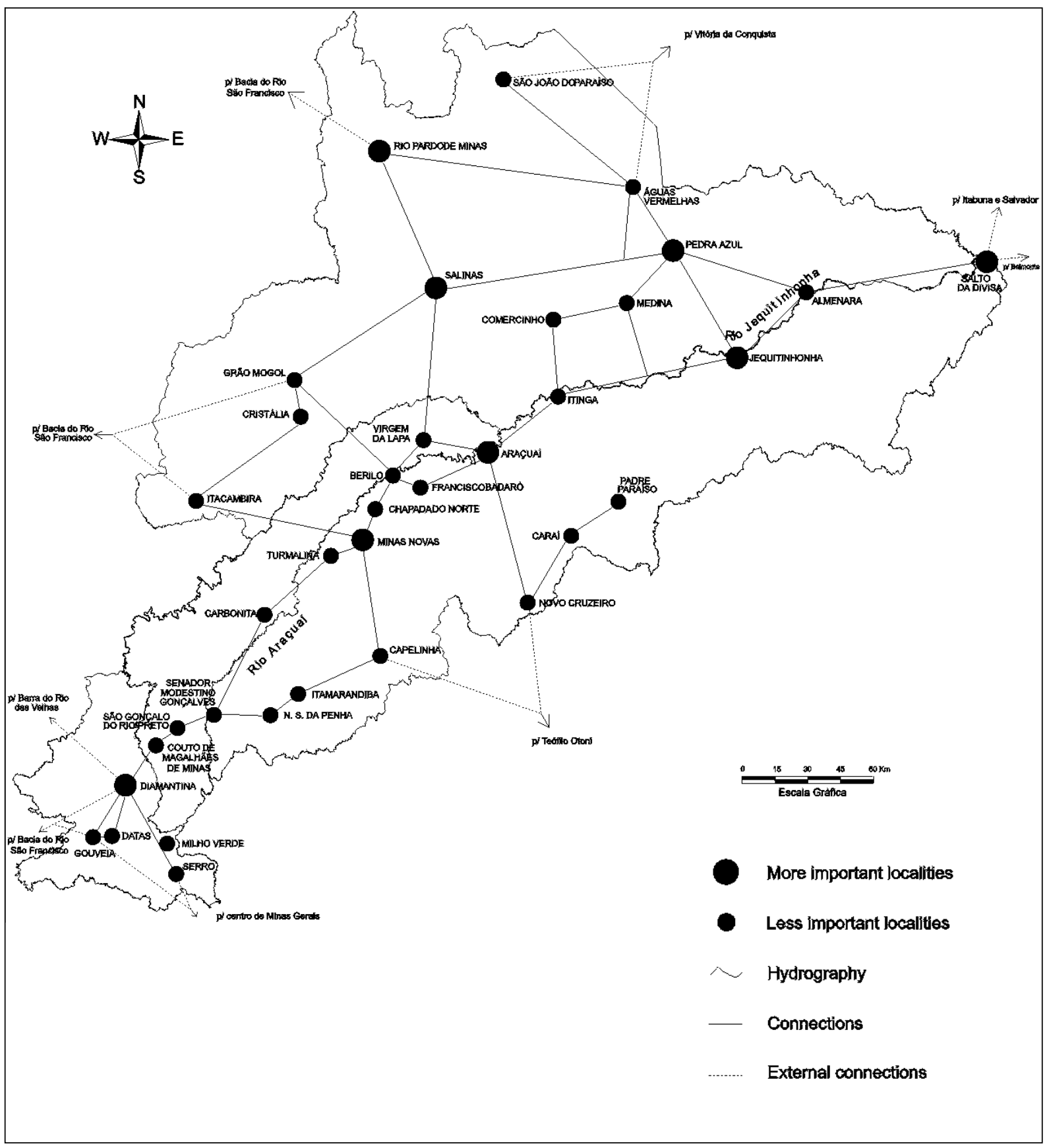

Mapa 3: Rede de localidades urbanas no Vale do Jequitinhonha no final do século XIX. Map 3: Network urban localities in Jequitinhonha Valley by the late 19th century. 
afirmação de Teófilo Otoni como centro urbano que polarizaria várias das localidades do médio e baixo Jequitinhonha. Embora o Mapa 3 só mostre parcialmente os caminhos entre Novo Cruzeiro, Padre Paraíso, Araçuaí e Teófilo Otoni, cabe ressaltar que este seria um dos vetores que produziriam a articulação entre as redes urbanas das respectivas regiões, durante boa parte do século XX.

\section{CONCLUSÃO GERAL}

Este trabalho constitui um primeiro esforço exploratório de apresentar a rede de lugares urbanos da Região do Jequitinhonha, procurando salientar a sua importância no interior da economia mineira entre os séculos XVIII e XIX.

Foi necessário identificar as mudanças mais importantes que vieram impactar o processo de urbanização, explicitando suas articulações com os desdobramentos derivados da mineração e, paralelamente, com os fluxos populacionais originários da Bahia. O garimpo, a agropecuária e o comércio, fatores constitutivos da estrutura sócio-espacial, forçaram a materialização de caminhos terrestres e fluviais que permitiriam introduzir maior vitalidade a rede de lugares do Jequitinhonha. Assim, atenção especial foi dada aos meios de transportes, pondo em relevo as limitações técnicas e as alternativas que se afiguravam na ocupação territorial, as quais foram desenhando, por assim dizer, o que viria a ser a estrutura da rede de lugares urbanos da Região.

Desta forma, foi essencial assinalar o $\mathrm{S}$ principais vetores sócio-espaciais da ocupação regional, sublinhando sua importância nos três momentos analisados no período. Os nexos de causalidade derivados dos arranjos institucionais protagonizados pela Coroa e população da área definida como "Demarcação Diamantina", que resultaram em um movimento de interiorização rumo ao Vale do Jequitinhonha foram especialmente relevantes, em face das especificidades econômico-espaciais que vieram aflorar, diferenciando a rede urbana em formação. Embora periférica à rede de cidades do centro de Minas, suas características singulares foram, e ainda o são em boa medida até hoje, capazes de realçar sua identidade, quando estabelece a importância histórica da extração de diamantes e pedras preciosas, as articulações e trocas populacionais com a Bahia, e a perversa trajetória da agropecuária, no médio e baixo curso do Vale, em face dos custos que a atividade imprimiu ao espaço geográfico anterior, no qual estavam presentes a Mata Atlântica, tribos indígenas e condições ambientais profundamente distintas das atuais.

Finalmente, cabe observar que as estruturas espaciais uma vez delineadas ganham características inerciais que geralmente resistem ao tempo, não obstante as mudanças que vão recobrindo a vida de relações dos lugares e populações locais. Assim, ainda hoje é perfeitamente possível visualizar a importância da rede de lugares que se desenvolveu no passado. Quaisquer alternativas de solução para o quadro de pobreza, que qualifica o Vale do Jequitinhonha, certamente deverão ter em conta a riqueza de seu processo de formação histórica.

\section{BIBLIOGRAFIA}

AMORIM FILHO, O . B. ; TAITSON BUENO, M. E. \& ABREU, J. F. Cidades de porte médio e o programa de ações sócioeducativo-culturais para as populações carentes do meio urbano em Minas Gerais" in: Boletim de Geografia Teorética, Rio Claro: 33-46. AGETEO. 1982.

ANTONIL, A .J. "Cultura e Opulencia do Brasil, por suas drogas e minas" (Lisboa. 1711). Rio de Janeiro. 1839.

AVELLAR, H. A . "História administrativa e econômica do Brasil" Rio de Janeiro, GB. MEC/FENAME. 1970.

ÁVILA, A .(coordenação e redação definitiva). "Minas Gerais: monumentos históricos e artísticos - Circuito do Diamante" Coleção Mineiriana. Série Municípios e Regiões. Revista BARROCO n ${ }^{\circ} 16$. Fundação João Pinheiro. Centro de Estudos Históricos e Culturais. Belo Horizonte, MG. 1994.

AZEVEDO, A . "Vilas e Cidades do Brasil Colonial. (Ensaio de geografia retrospectiva)" in: Revista "Terra Livre" n 10. São Paulo. AGB. 1994

AZEVEDO, A. (org) "Brasil: a terra e o homem" Volume II. A Vida Humana. São Paulo. Companhia Editora Nacional/ Editora da Universidade de São Paulo. 1970.

AZEVEDO, ANTÔNIO C. A . "Dicionários de nomes, termos e

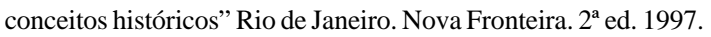

BARBOSA, W. A . "Dicionário Histórico-Geográfico de Minas Gerais" Belo Horizonte, MG.1971.

BOTELHO, T. R. \& PAIVA, C. A . "População e Espaço no Século XIX Mineiro: algumas evidências de dinâmicas diferenciadas" in: Anais do VII Seminário sobre a Economia Mineira.(Diamantina, MG). Volume1. Belo Horizonte, MG. CEDEPLAR/UFMG. 1995.

CARRATO, J. F. Igreja, Iluminismo e Escolas Mineiras Coloniais: notas sobre a cultura da decadência mineira setecentista. São Paulo: Cia. Editora Nacional/EDUSP, 1968.

CARVALHO, T. F. "Comarcas e Termos: creações, supressões, restaurações, encorporações e desmembramentos de comarcas e termos, em Minas Gerais (1709 - 1915)" Belo Horizonte, Imprensa Oficial, 1922. Censo Demográfico de Minas Gerais de 1872.

CHAVES, C. M. G. "Perfeitos Negociantes: Mercadores das Minas Setecentistas" Dissertação apresentada ao Curso de Mestrado na FAFICH/UFMG. Área de concentração: História das Relações Sociais de Dominação. Belo Horizonte, MG. 1995.

CORRÊA, R L. "Os Estudos das Redes Urbanas no Brasil até 1965" in: Simpósio de Geografia Urbana. Buenos Aires, Argentina. jun./ 1966. Publicação no 274 do Instituto Pan-Americano de Geografia e História. Rio de Janeiro. 1968

COSTA, J. R. "Toponímia de Minas Gerais - Com estudo histórico da divisão territorial administrativa" Belo Horizonte, MG. Imprensa Oficial do Estado. 1970.

COUTO, J.V. "Memória sobre a Capitania das Minas Gerais; seu território, clima e produções metálicas"(1799). Coleção Mineiriana. Série Clássicos. Fundação João Pinheiro. Centro de Estudos Históricos e Culturais. Belo Horizonte, MG. 1994.

DIAS, L. C. "Redes: emergência e organização" in: Castro, I. E. ; Gomes, P. C. C. e Corrêa, R. L. "Geografia: conceitos e temas" Bertrand Brasil. Rio de Janeiro. 1995.

FERNANDES, F. (organizador). "Comunidade e sociedade no Brasil: Leituras básicas de introdução ao estudo macro-sociológico do Brasil” São Paulo. Editora Nacional. 2a ed. 1975.

FERREIRA, J. P. (planejamento e orientação). "Enciclopédia dos Municípios Brasileiros” IBGE. Rio de Janeiro. 1957.

FRIEIRO, E. "Feijão, angu e couve: ensaio sobre a comida dos mineiros". Belo Horizonte, MG. Centro de Estudos Mineiros. Imprensa da UFMG. 1966. 
FUNDAÇÃO JOÃO PINHEIRO/ CODEVALE. "Vale do Jequitinhonha - Diagnóstico preliminar " Belo Horizonte, MG. 1975.

GARDNER, G. "Viagem ao interior do Brasil, principalmente nas províncias do Norte e nos distritos do ouro e do diamante durante os anos de 1836-1841" Trad. Milton Amado. Belo Horizonte, Editora Itatiaia; São Paulo, Editora da Universidade de São Paulo. Coleção: Reconquista do Brasil. 1975.

GEIGER, P. P. "Evolução da Rede Urbana Brasileira" Rio de Janeiro. GB. Instituto Nacional de Estudos Pedagógicos. MEC. 1963.

GUIMARÃES, A. P. (orientação) "Vale do Médio Jequitinhonha" Publicação do Grupo de Trabalho para a Pecuária. Belo Horizonte. 1960

HOLANDA, S. B. \& CAMPOS, P. M. (direção). "História Geral da Civilização Brasileira" São Paulo. Tomo I. Volumes $1^{\circ}$ "Do descobrimento à expansão territorial" e $2^{\circ}$ "Administração, Economia e Sociedade" Difusão Européia do Livro. 1973.

IGLÉSIAS, F. "Periodização da História de Minas Gerais", Revista Brasileira de Estudos Políticos, vol. 29, julho, 1970.

JACOB, R. (organizador) "Collectanea de Scientistas Extrangeiro (Assumptos Mineiros)" Volume II - Tomo I. Trad. Rodolpho Jacob. Belo Horizonte, MG. Imprensa Official de Minas Gerais. 1930.

LOPES, M. A . "A memória das tropas: recordações de tropeiros" in: Cadernos da FAFIDIA. Ano II . $\mathrm{N}^{\circ} 2$. Volume 1. Diamantina, MG. Jun / Jul 1993.

MARTINS, A. L. "Breve História dos Garimpos de Ouro no Brasil" in: Rocha, G. A .(organizador) "Em busca do ouro: Garimpos e garimpeiros no Brasil" Rio de Janeiro. Editora Marco Zero. 1984.

MARTINS, M. L. "Mineração, agricultura e degradação ambiental em Minas Gerais nos séculos XVIII e XIX" in: Cadernos da FAFIDIA. Ano II . $\mathrm{N}^{\circ}$ 2. Volume 1. Diamantina, MG. Jun / Jul 1993.

MARTINS, M. C. S. \& PAIVA, C. A. "População de Minas Gerais no século XIX" ; Martins, Roberto Borges e Martins, Maria C. S. "Novos estudos sobre a escravidão em Minas Gerais" Relatório de Pesquisa apresentado à FINEP. 1985.

MARTINS, M. C. S. Tabelas sobre a divisão administrativa municipal de Minas Gerais. in Martins, mímeo,1997.

MATOS, R. "Aspectos econômicos e retrospecto histórico das migrações em Minas Gerais" in: Anais do VII Seminário sobre a Economia Mineira. (Diamantina, MG). Volume1. Belo Horizonte, MG. CEDEPLAR/UFMG. 1995.

MELO, H. P. "Ferrovias e café: Rio de Janeiro e Minas Gerais 1850/ 1910" in: Anais do VII Seminário sobre a Economia Mineira. (Diamantina, MG). Volume1. Belo Horizonte, MG. CEDEPLAR/UFMG. 1995.

MENESES, J. N. C. "O Continente Rústico: o abastecimento alimentar na Comarca do Serro Frio, 1750 - 1810" Dissertação de Mestrado em História apresentada ao curso de Pós Graduação em História da FAFICH/UFMG. Belo Horizonte, MG. Jun/1997.

PAIVA, C. A. "População e economia na Minas Gerais do século XIX" Tese de doutorado. FAFICH/USP. São Paulo. 1996.

PAIVA, CLOTILDE ANDRADE. Tabelas sobre estimativas populacionais. in Paiva, mimeo, 1997.
PAULA, J.A . "O Prometeu no Sertão: Economia e Sociedade das Minas dos Matos Gerais" Tese de doutoramento apresentada à FAFICH da USP. São Paulo, SP.1988.

PEREIRA, W. "Cana, café \& laranja - História econômica de Nova Iguaçu” Rio de Janeiro. Fundação Getúlio Vargas/SEEC. 1977.

PETRONE, P. "Povoamento e colonização" in Azevedo, A. (org) "Brasil: a terra e o homem" Volume II. São Paulo. Companhia Editora Nacional/ Editora da Universidade de São Paulo. 1970

PRADO JÚNIOR, C. "Formação do Brasil Contemporâneo" São Paulo. Brasiliense. 13 a ed. 1973

RAISON, J. P. "Migração" in: "Enciclopédia Einaudi” v.8 Região. Porto, Portugal. Imprensa Nacional - Casa da Moeda. 1986.

RESENDE, M. E. L. \& MORAES, A . M. "Atlas Histórico do Brasil" Belo Horizonte, MG. Editora Vigília. 1987.

ROCHA, J. J. "Geografia Histórica da Capitania de Minas Gerais" (1781) Coleção Mineiriana. Fundação João Pinheiro. Belo Horizonte, 1995.

SAINT-HILAIRE, A. (1779-1853). "Viagem pelas Províncias do Rio de Janeiro e Minas Gerais" Trad. Vivaldi Moreira. Belo Horizonte, Editora Itatiaia; São Paulo, Editora da Universidade de São Paulo. Coleção: Reconquista do Brasil, v.4. 1975.

SALOMÃO, E. P. "O Ofício e a Condição de Garimpar" in: Rocha, G. A .(organizador) "Em busca do ouro: Garimpos e garimpeiros no Brasil" Rio de Janeiro. Editora Marco Zero. 1984.

SAMPAIO, T. "O rio de São Francisco e a Chapada Diamantina". Coleção de Estudos Brasileiros; Autores Nacionais. Série 1 ${ }^{\mathrm{a}}$. v.1. Bahia. Editora Cruzeiro. 1938.

SANTIAGO, L. \& SOUZA, M. G. C. "Pedra Azul: cinco visões de uma cidade" Prefeitura municipal de Pedra Azul/Jornal Boca das Caatingas. FUMARC. Pedra Azul. 1996.

SANTOS, J. F. (1828-1895). "Memórias do Distrito Diamantino da Comarca do Serro Frio" Belo Horizonte, Editora Itatiaia; São Paulo, Editora da Universidade de São Paulo. Coleção: Reconquista do Brasil. 1976.

SCLIAR, C. "Potencial Mineral do Alto Jequitinhonha" in: Cadernos da FAFIDIA. Ano I. $\mathrm{N}^{\circ}$ 1. Volume 1. Diamantina, MG. Out/ 1992.SILVA, J. "Tratado de Geografia descritiva especial da Província de Minas Gerais" (1877) Coleção Mineiriana. Fundação João Pinheiro. Belo Horizonte, 1997.

SILVA, L. V. "Redescobrindo as cidades mineiras oitocentistas" in: Anais do VII Seminário sobre a Economia Mineira.(Diamantina, MG). Volume1. Belo Horizonte, MG. CEDEPLAR/UFMG. 1995.

SOARES, J. "Atlas Histórico-Geográfico" Lisboa, Portugal. 1925.

SOL, O.F. "Salto da Divisa e outras considerações". s.e. Belo Horizonte, 1981.

SOUZA, J. M. "Cidade: momentos e processos - Serro e Diamantina na formação do norte mineiro no século XIX” Dissertação de Mestrado apresentada ao programa de Pós - Graduação em Sociologia da Faculdade de Filosofia da UFMG. Belo Horizonte, MG. 1991.

VASCONCELOS, D. P. R. "Breve descrição geográfica, física e política de Minas Gerais”(1807). Coleção Mineiriana. Série Clássicos. Fundação João Pinheiro. Centro de Estudos Históricos e Culturais. Belo Horizonte, MG. 1994.

VON ESCHWEGE, W.L. "Brasil, Novo Mundo" Trad. Domício de Figueiredo Murta. Coleção Mineiriana. Fundação João Pinheiro. Centro de Estudos Históricos e Culturais. Belo Horizonte, MG. 1996. 